ISSN: $1896-4087$

DOI: http://dx.doi.org/10.21784/ZC.2016.024

MARZENA FORMA

Akademia im. Jana Długosza w Częstochowie

\title{
Wanda Wasilewska jako autorka literatury adresowanej do dzieci i młodzieży
}

\section{Wanda Wasilewska as an author of the literature addressed to children and youth}

\section{Streszczenie:}

Wanda Wasilewska, znana pisarka i działaczka polityczna, w najnowszej historii jest postacią kontrowersyjną. Celem niniejszego tekstu było przypomnienie jej utworów adresowanych do dzieci i młodzieży: Kryształowa kula Krzysztofa Kolumba (1934), Królewski syn (1935), Szlakiem przygód (1935), Legenda o Janie z Kolna (1936), Wierzby i bruk (1936), Skrzydła u ramion (1939), W pierwotnej puszczy (1939). Literatura dziecięca powstała w latach 1933-1939 była owocem pracy Wasilewskiej, początkowo jako nauczycielki w krakowskich szkołach, później redaktorki w warszawskich pismach dla dzieci „Płomyk” i „Płomyczek”.

Słowa kluczowe: Wanda Wasilewska, utwory dla dzieci i młodzieży, opowiadania, „Płomyk” i „Płomyczek”

\section{Abstract:}

Wanda Wasilewska was known writer and political activist, in recent history is a controversial figure. The aim of this text was to remind her literature addressed to children and adolescents: The crystal ball of Christopher Columbus (1934), Royal Son (1935), Trail adventure (1935), The Legend of John from Kolno (1936), Willow and Paving (1936), Wings in arms (1939), In 
Marzena Forma - Wanda Wasilewska jako autorka...

the wilderness (1939). The children's literature was established in the years 1933-1939. This literature was the result of the Wasilewska work, first as an teacher in the Krakow schools, and later as an editor at warsaw's writings for children, „The flame” and „Flame”.

Key words: Wanda Wasilewska, works for children and young people, short stories, „The flame” and „Flame”

W okresie drugiej Rzeczpospolitej powstało wiele ciekawych książek dla dzieci i młodzieży, których autorami byli m.in. Jan Brzechwa, Kazimiera Iłłakowiczówna, Jerzy Korczak, Kornel Makuszyński, Anna Świrszczyńska. Do mniej znanych twórców z tego okresu należą: Maria Kownacka, Zofia Sawicka, Lucyna Krzemieniecka, Maria Kann1. Zrządzeniem losu Wanda Wasilewska², która napisała wiele utworów przeznaczonych dla młodzieży w ogóle nie jest kojarzona z tego typu literaturą. Autorka Ojczyzny (1934), Oblicza dnia (1936) oraz Ziemi wjarzmie (1938) w opracowaniach naukowych przyporządkowana jest najczęściej do lewicowego, rewolucyjnego nurtu literatury lat trzydziestych XX wieku - obok Władysława Broniewskiego, Leona

${ }^{1}$ Zob. J. Białek, Literatura dla dzieci i młodzieży w latach 1918-1939: zarys monograficzny, Warszawa 1987.

2 Wanda Wasilewska (ur. 1905 w Krakowie, zm. 1964 w Kijowie) - polonistka, pisarka, doktor filozofii, działaczka społeczno-polityczna. W latach 1923-1927 studiowała polonistykę i historię na Uniwersytecie Jagiellońskim w Krakowie. W trakcie studiów rozpoczęła działalność polityczno-oświatową, została członkiem Związku Niezależnej Młodzieży Socjalistycznej, Towarzystwa Uniwersytetu Robotniczego i Polskiej Partii Socjalistycznej. Po wybuchu drugiej wojny światowej udała się do Lwowa. Współuczestniczyła w powołaniu Związku Patriotów Polskich, 1Dywizji Piechoty im. Tadeusza Kościuszki, brała udział w pracach Polskiego Komitetu Wyzwolenia Narodowego. Ponadto współpracowała z radziecką i polskojęzyczną prasą („Nowe Widnokręgi”, „Wolna Polska”, „Czerwony Sztandar”) oraz tworzyła powieści o tematyce wojennej (np. trylogię Pieśń nad wodami). Po wojnie nie wróciła do kraju, lecz zamieszkała razem z trzecim mężem Aleksandrem Korniejczukiem w Kijowie; Archiwum Akt Nowych [dalej: AAN], Wspomnienia Wandy Wasilewskiej nagrane w Zakładzie Historii Partii przy KC PZPR w styczniu 1964 r., tecz. osob. Wandy Wasilewskiej, sygn. 9599. 
Kruczkowskiego i Władysława Kowalskiego ${ }^{3}$. Prozę jej zalicza się także do tzw. literatury upolitycznionej ${ }^{4}$, powieści politycznej ${ }^{5}$ (obok Leona Kruczkowskiego i Juliusza Kadena-Bandrowskiego) lub literatury chłopskiej ${ }^{6}$ (obok Leona Kruczkowskiego, Wojciecha Skuzy, Antoniego Olchy i Mariana Czuchnowskiego). „W Ojczyźnie doszukiwano się zbieżności z literaturą Elizy Orzeszkowej. Ze względu na stale powtarzający się motyw dziecka i dzieciństwa zestawiano utwory Wasilewskiej z Bolesławem Prusem"7. Natomiast druga kontrowersyjna książka W. Wasilewskiej Oblicze dnia przez krytyków literackich uznana została za kontynuację Przedwiośnia Stefana Żeromskiego8. Zanim jednak Wasilewska, polonistka i rozpoznawalna działaczka polityczna oraz córka ministra spraw zagranicznych w II RP - Leona Wasilewskiego ${ }^{9}$, wydała przed wybuchem drugiej wojny światowej trzy swoje głośne powieści, trudniła się pisaniem utworów, które były adresowane do znacznie młodszego grona odbiorców. Powstała w latach 19331939 literatura dziecięca była owocem pracy Wasilewskiej, początko-

\footnotetext{
3 Z. Wasilewski, Słowo wstępne, [w:] A. Naborowska (oprac.), Wanda Wasilewska: wieczór literacki, Warszawa 1954, s. 4.

${ }^{4}$ Z. Jarosiński, Literatura i nowe społeczeństwo. Idee lewicy dwudziestolecia międzywojennego, Warszawa 1983.

${ }^{5}$ H. Małgowska, Nowa formuła powieści społecznej, [w:] A. Brodzka, Z. Żabicki (red.), Z problemów literatury polskiej XX wieku, T. 2, Warszawa 1965, s. 403.

${ }^{6}$ Termin ten w okresie dwudziestolecia międzywojennego służył do określenia literatury podejmującej temat wiejski z pozycji rewolucyjnych.

7 M. Forma, Działalność kulturalno-literacka Wandy Wasilewskiej w latach 19341945, „Zeszyty Naukowe Państwowej Wyższej Szkoły Zawodowej we Włocławku. Zbliżenia Cywilizacyjne. Edukacja, kultura, polityka" 2014, T. 10, s. 181.

8 Zob. H. Zatorska, Wanda Wasilewska, Warszawa 1976, s. 35.

${ }^{9}$ Leon Wasilewski (ur. 1870 w Petersburgu, zm. 1936 w Warszawie) - historyk, polityk, etnograf i literat. Znany i ceniony działacz PPS oraz bliski współpracownik Józefa Piłsudskiego. W drugiej Rzeczpospolitej piastował wiele ważnych funkcji: był ministrem spraw zagranicznych $\mathrm{w}$ rządzie Jędrzeja Moraczewskiego, posłem RP w Estonii, delegatem na pokojową konferencję w Paryżu oraz na konferencję państw bałtyckich w Helsinkach. Zob. AAN, Akta Leona Wasilewskiego 1890-1936 [1937], tecz. osob. Leona Wasilewskiego, sygn. 390; A. Friszke, Jeden $z$ „niepokornych” Leon Wasilewski, [w:] L. Wasilewski, Piłsudski jakim go znałem, Warszawa 2013, s. 9-108; W. Pobóg-Malinowski, Leon Wasilewski. Szkic biograficzny, „Niepodległość” 1937, T. 16, s. 11-106; B. Stoczewska, O Leonie Wasilewskim, http://www.omp.org.pl/ stareomp/index7c3b.html (dostęp: 15.01.2015).
} 
Marzena Forma - Wanda Wasilewska jako autorka...

wo jako nauczycielki w krakowskich szkołach, później redaktorki w warszawskich pismach dla dzieci. Jesienią 1934 roku nie przedłużono Wasilewskiej umowy w gimnazjum, dlatego razem z rodziną przeniosła się z Krakowa do Warszawy. Od 1935 roku pracowała w Związku Nauczycielstwa Polskiego oraz w redakcji „Płomyka”10 i „Płomyczka”11. Nakład 25 numeru „Płomyka” z marca 1936 roku poświęcony Związkowi Radzieckiemu „został skonfiskowany przez władzę, a działalność Zarządu Głównego ZNP zawieszona, Wasilewskiej postawiono zarzut agitacji komunistycznej oraz bolszewizowania polskich dzieci"12. W lipcu 1938 roku została zwolniona z redakcji pisma za zorganizowanie, wspólnie z Janiną Broniewską i pozostałymi członkami redakcji, strajku pracowników Związku. Po tym zdarzeniu nawiązała współpracę z pismem dla dzieci i młodzieży, w którym drukowano przygody disnejowskich bohaterów. Jej zadanie polegało na tłumaczeniu tekstów umieszczanych pod obrazkami. Pisała również teksty do audycji nadawanych w Polskim Radiu.

Powstałe w tym okresie utwory dla dzieci i młodzieży Józef Zbigniew Białek, z uwagi na tematykę, podzielił na dwie zasadnicze grupy: „pierwszą tworzą teksty o charakterze obyczajowym, bliskie radykalnemu nurtowi prozy lat trzydziestych (Górska, Boguszewska, Kornacki), drugą - opowieści i opowiadania historyczne, biograficzne, przyrodnicze"13. Klasyfikacja ta jest jak najbardziej poprawna. Pierwsze utwory Wandy Wasilewskiej dla dzieci i młodzieży poświęcone były znanym postacią historycznym. Owe opowieści z dziejów ojczystych, podobnie jak w dobie pozytywizmu i nieustannych walk wyzwoleń-

10 „Płomyk” - tygodnik ilustrowany dla dzieci i młodzieży, który ukazywał się w latach 1917-1991. Pierwszym wydawcą pisma był Związek Polskiego Nauczycielstwa Szkół Powszechnych, a od 1930 roku Związek Nauczycielstwa Polskiego. 2013

11 „Płomyczek” - czasopismo młodzieżowe, które ukazywało się w latach 1917-

12 M. Forma, Działalność polityczno-literacka Wandy Wasilewskiej w latach 19391943, [w:] R. Majzner (red.), Między prawdq a zwątpieniem. W poszukiwaniu obrazu przeszłości, T. 3, Częstochowa 2015, s. 322.

13 J. Białek, Literatura dla dzieci i młodzieży..., s. 293. 
czych, miały na uwadze nie tylko względy poznawcze, lecz przede wszystkim cele wychowawcze.

W 1925 roku seria „Biblioteki Książek Różowych” wydała dwa teksty Wandy Wasilewskiej: Goście z całego świata (wydanie oddzielne w 1933 r.) i Opowieść o człowieku pierwotnym (wydanie oddzielne w 1934 r.). Następnie ukazały się kolejne opowiadania historyczne, biograficzne i przygodowe takie jak: Kryształowa kula Krzysztofa Kolumba (1934), Królewski syn (1935), Szlakiem przygód (1935), Legenda o Janie z Kolna (1936), Wierzby i bruk (1936), Skrzydła u ramion (1939), W pierwotnej puszczy (1939).

\section{Opowiadania historyczne, biograficzne i przygodowe}

Kryształowa kula Krzysztofa Kolumba (1934) opisuje wczesne dzieciństwo jednego z najsłynniejszych XV wiecznych odkrywców i żeglarzy. Życie prywatne Kolumba zawsze owiane było tajemnicą, dlatego niewiele wiadomo na temat jego lat młodzieńczych. Biografie odkrywcy Ameryki konstruowane według schematu narracji hagiograficznej idealizują jego czyny od najmłodszych lat. W opowiadaniu Wasilewskiej Krzysztof już od dziecka chciał zostać marynarzem. Jego ojciec pragnął natomiast, aby syn zdobył konkretny zawód; posyłał go na praktykę do piekarza, kupca, szewca, farbiarza ubrań. Chłopiec wolał podróżować, odkrywać nieznane lądy wraz z ich mieszkańcami. Fascynowały go egzotyczne kultury, rośliny i zwierzęta. Nie raz wyobrażał sobie jak wraca z takiej podróży, a ludzie w porcie głośno nawołują i podziwiają go za skarby, które przywoził z tych eskapad. Marzył o sławie. Pewnego dnia udał się do wróżki, w której kuli zobaczył swoją przyszłość. Wyprawy do odległych krain wcale nie zapewniły mu dobrobytu, lecz były przyczyną nienawiści, chorób, więzienia i śmierci. Mimo to Krzysztof postanowił iść obraną wcześniej drogą, ponieważ był świadomy swojej misji - musiał wybawić ludzi od głodu. Ujrzał w kuli twarze dzieci, które w czasach biedy żywiły się bulwami ziemniaków, przywiezionych przez niego z Ameryki do Europy. W po- 
Marzena Forma - Wanda Wasilewska jako autorka...

dobny sposób Kolumb ratuje od głodu mieszkańców Europy w poemacie Adama Mickiewicza pt. Kartofla. Jednak przesłanie wypływające $\mathrm{z}$ opowiastki Wasilewskiej brzmi następująco: należy wierzyć w siebie i spełniać marzenia, ale nie dla nagród i chwały, lecz dla dobra innych. Prezentując osobę Kolumba autorka zwróciła uwagę na takie cechy jego charakteru jak odwaga, silna wola i pasja odkrywcza. Wanda Wasilewska w okresie międzywojennym nie była jedyną pisarką, która próbowała odtworzyć losy tego słynnego na całym świecie żeglarza i podróżnika. Zainteresowanie literaturą podróżniczą w Polsce na przełomie XIX i XX wieku było całkiem spore. Kolumb stał się bohaterem wiersza Cypriana K. Norwida Coś ty Atenom zrobił, Sokratesie (1856) oraz powieści Tadeusza Peipera Krzysztof Kolumb odkrywca (1949) ${ }^{14}$.

Opowiadanie Królewski syn (1935) poświęcone zostało Kostce Napierskiemu15, który w1651 roku próbował wszcząć powstanie chłopskie na Podhalu. Był on najprawdopodobniej synem króla Władysława IV. Niektórzy historycy są zdania, iż Kostka Napierski miał kontakty z Bohdanem Chmielnickim. W podobny sposób o pochodzeniu bohatera pisała sama Autorka:

Kimże on był (...). Był ponoć królewskim synem. Nieprawe dziecko królewskie odziedziczyło po ojcu, Władysławie IV, królewską dumę, ambitne plany, wojowniczego ducha rycerzy, despotyczną naturę władców.

Starano się widać o to, by chłopak otrzymał odpowiednie wychowanie. Oddano go na jeden z najbardziej zasłużonych dworów - dwór rodziny Kostków, których nazwiskiem będzie się potem posługiwał królewski syn ${ }^{16}$.

14Zob. J. Tazbir, Polska sława Krzysztofa Kolumba, Warszawa 1991; tegoż, Kilka wierszy o Krzysztofie Kolumbie, „Przegląd Humanistyczny” 1993, nr 6, s. 1-5.

15 Aleksander Kostka-Napierski (ur. 1617, zm. 18 lipca 1651 w Krakowie) - oficer wojsk konnych, według jednej z hipotez wywodził się ze szlacheckiego rodu z Mazowsza. W 1651 roku przy pomocy powstańców chłopskich zajął zamek w Czorsztynie. Powstanie jednak zostało stłumione, a jego przywódca został skazany na karę śmierci poprzez nabicie na pal. Zob. K. Lepszy, Słownik biograficzny historii powszechnej do XVII stulecia, Warszawa 1968, s. 266-267.

${ }_{16}$ W. Wasilewska, Królewski syn, [w:] tejże, Utwory dla młodzieży, Warszawa 1954, s. 438. 
W opowieści Wasilewskiej młody Kostka, który naprawdę nazywał się Wojciech Stanisław Bzowski dorastał na dworze królowej Cecylii Renaty Habsburżanki, pierwszej żony Władysława IV Wazy oraz jako paź uczestniczył w życiu kulturalnym oraz był świadkiem intryg, tajnych układów i bezwzględnej walki o władzę. W tym okresie pisarka upatruje początków oraz źródeł jego nienawiści do szlachty i magnatów. W walce chciał wykorzystać chłopów, którym obiecał wyzwolenie spod pańskiego ucisku, zapewniając ich jednocześnie, że król Jan Kazimierz solidaryzuje się z powstańcami. Przy pomocy nauczyciela Marcina Radockiego wszedł w posiadanie fałszywych rozkazów na nazwisko Napierski (przedtem był znany jako Aleksander Leon ze Szternberku) i jako królewski pułkownik zorganizował między innymi na Podhalu zaciąg wojsk. W czerwcu 1651 roku zajął zamek w Czorsztynie. Po dwudniowym oblężeniu przegrał $\mathrm{w}$ walce $\mathrm{z}$ żołnierzami wysłanymi przez krakowskiego biskupa Piotra Gębickiego. Za wzniecenie buntu został skazany na karę śmierci poprzez nabicie na pal. W tekście Wasilewskiej dwie rzeczy zwracają uwagę. Autorka wykazuje się znakomitą znajomością historii Polski. Fakt ten jednak nie dziwi, gdyż po obronie pracy magisterskiej pt. Podhale u Witkiewicza i Tetmajera na Uniwersytecie Jagiellońskim, na podstawie której nadano jej tytuł doktora filozofii, Wasilewska postanowiła dalej kontynuować swoją edukację. Przez dwa lata na wydziale historii kultury uczęszczała na seminarium prowadzone przez prof. Stanisława Kota oraz napisała pracę historyczną pt. Marcin Czechowicz. Z dziejów ariaństwa polskiego ${ }^{17}$. Pisarka mocno akcentuje klasowy charakter państwa polskiego: naród dzieli się na klasę panującą (szlachtę i margrabiów) oraz na biednych, uciśnionych chłopów. Wątek ten będzie stale powracał w powieściach Wasilewskiej, zarówno w tych przedwojennych jak Ziemia w jarzmie (1938), pisanych w czasie wojny - Płomień na bagnach (1940) i w jej twórczości powojennej - Rzeki płonq (1952).

\footnotetext{
${ }^{17}$ Archiwum Uniwersytetu Jagiellońskiego [dalej: AUJ], Teczka akt doktorskich Wandy Wasilewskiej-Szymańskiej, sygn. WF II 504.
} 
Marzena Forma - Wanda Wasilewska jako autorka...

Szlakiem przygód (1935) to opowieść o dwóch dzielnych młodzieńcach, synu krakowskiego starosty Kaźko i jego pachołka Stanko, którzy zostali porwani przez sługę Iwana. Chłopcy wspólnie przemierzają nieznane im lasy i bory, walczą z dzikimi zwierzętami, odnajdują kryjówkę rzezimierzków. W końcu, przy pomocy górala Andre, doprowadzają do procesu zdrajców. Utwór w całości napisany został gwarą, którą pisarka doskonale znała. Wasilewska będąc dzieckiem często chorowała, dlatego też rodzice wysyłali ją za miasto, do Radziszowa i Zagacia lub w okolice Zakopanego. Latem 1914 roku Wasilewska razem z młodszą siostrą przebywały na letnisku we wsi Żarnówka koło Makowa Podhalańskiego. Tam też mała Dziuńka spędziła lata I wojny światowej pod opieką blisko siedemdziesięcioletniej babki, ponieważ oboje jej rodzice zaangażowani byli w walki niepodległościowe. Przedłużający się pobyt w Żarnówce umożliwił Wasilewskiej poznanie zwyczajów i obyczajów chłopów oraz wierzeń i zabobonów, które skrzętnie zapisywała w zeszycie. Historie te wykorzystywała później przy pisaniu swoich powieści i opowiadań dla dzieci. W utworze zwracają uwagę kolorowe ilustracje nieznanego artysty oraz drobiazgowe opisy przyrody, która z jednej strony jest tajemnicza i groźna, $\mathrm{z}$ drugiej - zachwyca swoim pięknem. A oto jeden z nich:

Przed nimi roztaczała się szeroka dolina. Środkiem płynął bystry strumień. Na zielonych, rozkwitłych łąkach wznosiły się gdzieniegdzie wysokie, grube modrzewie w puszystym, delikatnem igliwiu. Gdzieniegdzie ciemniał cis. Wielkie, barwne kielichy kwiatów tkwiły w wysokiej trawie, jak gwiazdy. Liście dzikiego szczawiu zarastały wybrzeże potoku, mieszając się z włochatemi parasolami łopuchów. W zalewie słonecznych blasków dolina wyglądała jak jakiś zaczarowany kraj, ciągnęła ku sobie znużone półmrokiem boru oczy z nieprzemożoną siłą. Dal tonęła w błękitnych oparach ${ }^{18}$.

Legenda o Janie z Kolna (1936) opowiada historię sługi króla Władysława III, który po śmierci swojego władcy i przyjaciela, porzucił żołnierski fach i został żeglarzem w służbie duńskiego króla Christiana I. Jan z Kolna bowiem po przegranej bitwie z Turkami w 1444 roku

18W. Wasilewska, Szlakiem przygód, Warszawa 1936, s. 74. 
pod Warną, dość miał walki z ludźmi, zapragnął wojować z morzem. Marzył również o odkryciu nieznanego Europejczykom lądu, położonego na obszarze północnego Atlantyku, za Islandią i za Grenlandią. Zakończenie utworu jest mgliste i niejasne, nie mówi wprost czy bohaterowi udało się osiągnąć cel, bowiem jego statek wpłynął między góry lodowe. Opowiadanie Wasilewskiej stanowi nawiązanie do legendy o polskim podróżniku z XV wieku, Janie z Kolna, zwanym niekiedy w zapiskach Johannem Scolvusem czy Scolusem (ur. ok. 1935, zm. ok. 1984), który rzekomo w 1476 roku jako pierwszy (szesnaście lat przed Krzysztofem Kolumbem) dotarł do wybrzeży Ameryki. Janusz Tazbir zwraca uwagę, że w okresie zaborów i wojen badacze często wskazywali na polskie korzenie znanych i zasłużonych postaci historycznych, bowiem rekompensowali $\mathrm{w}$ ten sposób emigracyjne kompleksy charakterystyczne dla Polaków w okresie niewoli19. Dzisiaj trudno udowodnić prawdziwość tej hipotezy. Niemniej postać legendarnego podróżnika znalazła swoje odbicie w literaturze i sztuce. Stała się inspiracją dla wielu polskich artystów, m.in. malarza Jana Matejki, rzeźbiarza Aleksandra Żurakowskiego, pisarza Stefana Żeromskiego ${ }^{20}$. Natomiast Wasilewska opisując perypetie tego Polaka i nawigatora floty duńskiej, zwróciła uwagę na przesądy, wierzenia i mitologię żeglarską. Ponadto książeczka została wzbogacona o ilustracje, których autorem był znany grafik i malarz - Zbigniew Łoskot.

W pierwotnej puszczy (1939) to zbiór opowieści poświęcony czasom prehistorycznym. Bohaterami poszczególnych historii są spersonifikowane żywioły (woda, ogień, krzemień, glina i ziemia) oraz zwierzęta (pies, krowa), z którymi słaby i nieporadny człowiek zawarł

19 J. Tazbir, Zainteresowanie Kolumbem w Polsce XIX i XX wieku, „Kwartalnik Historii Nauki i Techniki", nr 34/3, s. 468, http://bazhum.muzhp.pl/media//files/ Kwartal nik_Historii_ Nauki_i_Techniki/Kwartalnik_Historii_Nauki_i_Techniki-r1989-t34-n3/ Kwartalnik_Historii_Nauki_i_Techniki-r1989-t34-n3-s463-482/ Kwartalnik_Historii_ Nauki_i_Techniki-r1989-t34-n3-s463-482.pdf (dostęp: 06.02.2017).

${ }^{20}$ Jan z Kolna - Polak, który odkrył Amerykę, http://www.dziennik.com/publicy styka/artykul/jan-z-kolna-polak-ktory-odkryl-ameryke (dostęp: 06.02.2017); J. Tazbir, Zainteresowanie Kolumbem w Polsce XIX i XX wieku..., s. 469-470. 
Marzena Forma - Wanda Wasilewska jako autorka...

przymierza. Z czasem jednak nauczył się korzystać z ich właściwości, zniewolił siły przyrody choć te próbowały mu przypomnieć kto w tym układzie jest Panem a kto niewolnikiem. Człowiek często zapominał o warunkach zawartych umów i zaniedbywał zwierzęta, które mu wiernie służyły. Najgorzej jednak wiodło się przymierzu człowieka z człowiekiem bowiem ludzie nie mogli się ze sobą porozumieć, zabijali się, wytyczali granice na mapie i w sercu. Opowiadanie ma na celu przypomnienie niegdyś obowiązujących zasad. Autorka na końcu utworu zwraca się do Czytelnika tymi oto słowami:

Dlatego napisałam tę książkę, żeby przypomnieć tobie, który jesteś jeszcze mały, o przymierzach zawartych ongiś na polanie pierwotnej puszczy. (...) Kiedy zaś przyjdzie taka chwila, że zechcesz niesłusznie uderzyć psa albo dokuczyć koniowi pasącemu się spokojnie na łące - przypomnij sobie o przymierzu zawartym ongiś na polanie pierwotnej puszczy. (...) A były tam trzy warunki, o których nie powinieneś zapominać: miejsce przy ogniu, kęs strawy i dobre obchodzenie się. Musisz o tym pamiętać, bo zwierzę, które cię karmi, daje ci odzież i opiekę, dochowało przymierza.

Ale nade wszystko chciałabym, żebyś pamiętał o przymierzu człowieka z człowiekiem. Żebyś pamiętało nim, jeśli przyjdzie na ciebie taka zła chwila, że bliski będziesz skrzywdzenia człowieka. Bo przymierze zawarte zostało także w moim i twoim imieniu i zawarto je nie na dzień ani na dwa dni, ale po wszystkie dni, póki żył będzie człowiek ${ }^{21}$

Ostatnie opowiadanie pt. Skrzydła u ramion Wasilewska ukończyła w sierpniu 1939 roku, na dwa miesiące przed wybuchem drugiej woj.ny światowej. Autorka opisała w nim historię młodego władcy z dynastii Piastów, Przemysława II (ur. 1257, zm. 1296), który był piątym, najmłodszym synem księcia wielkopolskiego, Przemysława I. Wychowywał się on na dworze swojego stryja Bolesława Pobożnego, po śmierci którego przejął jego włości i w 1295 r. koronował się na króla Polski. Niecały rok później, 8 lutego 1296 r. został zamordowany przez margrabiów brandenburskich. Opowiadanie to niewątpliwie jest owocem zainteresowań Wasilewskiej, która w latach 1923-1927

\footnotetext{
21 W. Wasilewska, W pierwotnej puszczy, [w:] tejże, Utwory dla młodzieży, Warszawa 1954, s. 111-112.
} 
studiowała filologię polską, a po obronie pracy magisterskiej postanowiła kontynuować edukację jeszcze przez dwa lata na wydziale historii kultury 22 . W latach 30 . XX wieku w dobie wzmożonego zagrożenia ze strony faszystowskich Niemiec utwór ten stanowił ostrzeżenie przed zachodnim sąsiadem. Jednocześnie wzywał do walki, przypominając, że wojny z Niemcami trwają od czasów dynastii piastowskiej, a Polacy nadal nie wyrównali rachunków za przelaną krew.

\section{Opowiadania obyczajowe}

Wierzby i bruk (1936) to przejmująca pogadanka pokazująca w jaki sposób zmienia się sytuacja materialna rodziny po śmierci jej żywiciela i opiekuna. Po nagłym zgonie męża kobieta z trójką małych dzieci nie jest w stanie utrzymać gospodarstwa na wsi. Sprzedaje ziemie oraz trzodę chlewną i przeprowadza się do miasta. Pracuje w pocie czoła jako praczka mimo to nie jest w stanie utrzymać domu. Odpowiedzialność za losy rodziny przejmuje najstarszy z synów, Wicek, który w wieku trzynastu lat postanawia podjąć pracę na budowie. Ból fizyczny, obolałe mięśnie nie są dla niego ważne, ponieważ ma świadomość, że dzięki jego pracy rodzina może być razem. Postać głównego bohatera wzorowana była najprawdopodobniej (tak samo jak w przypadku Anatola z Oblicza dnia) na murarzu i drugim mężu23 Wa-

\footnotetext{
22 Archiwum Uniwersytetu Jagiellońskiego [AUJ], Teczka akt doktorskich Wandy Wasilewskiej-Szymańskiej, sygn. WF II 504.

${ }^{23}$ Wanda Wasilewska była czterokrotnie zamężna. Jej pierwszym partnerem życiowym był Roman Szymański, syn robotnika kolejowego z Tuchowa, który zmarł w 1931 roku na tyfus brzuszny. Po śmierci Szymańskiego, z którym miała córkę Ewę, związała się z murarzem Marianem Bogatko, zastrzelonym we Lwowie w 1940 roku. Jej trzecim oficjalnym mężem w 1941 roku został ukraiński pisarz i działacz komunistyczny - Aleksander Korniejczuk. Marian Czuchnowski w swoim utworze pt. Z Moskwy do... Moskwy (1944) podaje, że zanim Wasilewska wyszła za mąż za Korniejczuka, związała się z aktorem, który grał główną rolę w jej przedstawieniu pt. Opowieść o Bartoszu Głowackim. Z recenzji zamieszczonych w „Czerwonym Sztandarze” (23 III 1941) udało się ustalić, że odtwórcą tytułowego Bartosza Głowackiego był Lech Ludwik Madaliński.
} 
Marzena Forma - Wanda Wasilewska jako autorka...

silewskiej, Marianie Bogatce 24 . Według opinii Aleksandra Wata był z niego „fantastyczny atleta, piękny rzeczywiście chłopak do tańca i różańca. Bardzo inteligentny, bystry, z poczuciem humoru, szalenie wesoły, silny chłop"25. Bogatko jednocześnie czytał i wprowadzał poprawki do powieści Wasilewskiej. W liście do matki na temat umiejętności literacko-korektorskich męża Wanda pisała:

Jestem teraz w trakcie pisania wielkiej powieści, ale to pójdzie dość wolno, bo muszę do tego dużo czytać i opracowywać porządnie. Marjan piłuje mnie w niesłychany sposób. Węszy braki i felery już nie tylko w każdej stronie ale w każdem zdaniu. Książce wyjdzie to zresztą tylko na dobre. Zdaje mi się, że Marjan mógłby także pisać - bodaj lepiej odemnie. Wszystko, co zmienię według jego uwag, jest stanowczo lepsze, niż wpierw²6.

Marian Bogatko został zastrzelony przez funkcjonariuszy NKWD we Lwowie wiosną 1940 roku, ponieważ sprzeciwiał się współpracy Wasilewskiej z komunistami. Zachowanie pisarki po śmierci Bogatki uległo diametralnej zmianie. Włodzimierz Sokorski twierdził, iż od tego momentu stała się „,serwilistycznie radziecka”27.

Na przełomie lat 1936-37 na łamach „Płomyka” ukazywały się opowiadania'28, które w 1939 roku złożyły się na książkę pt. Pokój na poddaszu. Utwór ten do 1989 roku znajdował sie w spisie lektur obo-

${ }^{24}$ Marian Bogatko (ur. 17 marca 1906 r. w Krzepicach, zm. 25 lub 26 maja 1940 roku we Lwowie) - działacz społeczno-politycznych, który z zawodu był robotnikiem murarskim. Członek PPS oraz OMTUR, sekretarz Związku Zawodowego Murarzy, administrator „Dziennika Popularnego”, pracownik redakcji pisma „Płomienie”, organizator strajku generalnego murarzy w Krakowie w 1933 roku. Został zastrzelony w 1940 r. we Lwowie przez NKWD, w mieszkaniu wynajmowanym przez starszą siostrę Wasilewskiej.

${ }^{25}$ A. Wat, Mój wiek. Pamiętnik mówiony, T. 1, Warszawa 1990, s. 284.

${ }^{26}$ AAN, Z.A. Woźnicka, Wspomnienia o Wandzie Wasilewskiej, tecz. osob. Wandy Wasilewskiej, sygn. 9599, k. 436.

27 W. Sokorski, Adieu, burdel czyli notatnik intymny, Chicago - Warszawa 1992, s. 23.

${ }^{28}$ Na łamach „Płomyka” ukazały się następujące fragmenty Pokoju na poddaszu: 1936, nr 1 (Rozdział 1); nr 3 (Rower); nr 5 (Pożar); nr 7 (Krzak bzu); nr 9 (Wypadek); nr 10 (Na podwórku); nr 13 (Pani Kalinowska); nr 14 („Zwykła” bawełna); nr 16/17 (Choinka); 1937, nr 2 (Kamizelka); nr 19 (Wózek); nr 21 (Kamizelki); nr 23 (Helenka); nr 25 (bez tytułu); nr 27/28 (Święta); nr 30 (bez tytułu); nr 31 (Imieniny); nr 33 (Szofer); nr 37 (Nowe mieszkanie); nr 39/40 (bez tytułu). 
wiązkowych. Jego bohaterami jest czwórka dzieci-sierot: Anka, Ignaś, Adaś, Zosia. Anka jako najstarsza z rodzeństwa, aby zapewnić byt materialny rodzinie, podejmuje wyniszczającą fizycznie pracę $\mathrm{w}$ fabryce bawełny. Pozostała trójka dzieci pomaga jej w obowiązkach domowych. Postawa jaką przyjmują zbliża ich niekiedy do ludzi w pełni dorosłych i dojrzałych emocjonalnie. Ignaś, aby odciążyć finansowo siostrę, sprzedaje jedyną rzecz, którą posiada - rower, dzięki któremu może jeździć za miasto. Często również w celu zarobkowym podejmuje różne prace sezonowe. Zosia gasi pożar oraz ratuje sparaliżowaną babkę Kalinowską przed zaczadzeniem, kalecząc sobie przy tym ręce. Anka zaś walczy z antysemityzmem, tłumacząc osiedlowym dzieciom, że ich kolega Chaimek - syn żydowskiego szewca, nie jest wcale od nich gorszy. Ponadto adoptuje jeszcze jedno niepełnoletnie dziecko Helenkę, która po śmierci dziadka, staje się sierotą.

Wasilewska w Pokoju na poddaszu podejmuje dwie ważne kwestie. Po pierwsze jasno daje do zrozumienia, że miasto nie sprzyja aktywności psychofizycznej dzieci, czym nawiązuje do myśli Jana J. Rousseau $^{29}$. Znacznie lepszym miejscem dla wszechstronnego rozwoju jest wieś, między innymi poprzez stały kontakt z naturą. Kwestia druga również związana jest $\mathrm{z}$ wychowaniem dzieci. Od najmłodszych lat powinny one współpracować ze sobą, tak aby ich działania przynosiły korzyści reszcie społeczeństwa. Tym samym praca jest traktowana jako wartość, zarówno z punktu widzenia jednostki, jak i całego społeczeństwa. W ramach jednego zawodu za wykonywaną pracę wszyscy robotnicy (bez względu na płeć) powinni otrzymywać takie samo wynagrodzenie. Praca jest wartością absolutną, jest czynnikiem wszechstronnego rozwoju człowieka, decyduje o jego miejscu w społeczeństwie i poczuciu socjalnego bezpieczeństwa. Praca Anki jest przede wszystkim pożyteczna. Pomimo że wyczerpuje ją fizycznie czuje się dzięki niej potrzebna i spełniona. Młodszy brat codzienny wysiłek dziewczyny podsumowuje następująco: „Przecież ty dajesz

${ }^{29}$ Jan J. Rousseau (ur. 28 czerwca 1712 w Genewie, zm. 2 lipca 1778 w Ermenonville) - pisarz tworzący w języku francuskim, filozof, pedagog. 
Marzena Forma - Wanda Wasilewska jako autorka...

ludziom ubranie, robisz płótno na bandaże i na poduszki dla niemowląt, i na sukienki dla dzieci, i na wszystko, wszystko"30. Hasła zawarte w tym utworze niewątpliwie odpowiadają socjalistycznym przekonaniom Wasilewskiej z tego okresu. Warto przypomnieć, że pisarka w latach 1934-1937 była członkiem Rady Naczelnej PPS, gdzie reprezentowała lewicowe skrzydło partii.

\section{Pozostałe utwory}

Wiele tekstów dla dzieci i młodzieży Wasilewska jako redaktorka zamieściła na łamach „Płomyka” i „Płomyczka”. Niektóre z nich to: Jak Jerzy Bajan został lotnikiem?, „Płomyk” 1934, nr 7; Wspomnienie z roku 1915, „Płomyk” 1934, nr 12; Jak Janek został Sindbadem Żeglarzem, „Płomyczek” 1935, nr 1; Przyjaciele, „Płomyk” 1935, nr 3. U zegarmistrza, „Płomyczek” 1936, nr 2; Noc trzech króli, „Płomyczek” 1936, nr 18; Legenda o Janie z Kolna, „Płomyk” 1936, nr 26. Twórczość dla dzieci i młodzieży Wandy Wasilewskiej zamknęła się właściwie w latach międzywojennych. Po wybuchu II wojny światowej udała się do Lwowa. Na terytorium okupowanym przez ZSRR brała aktywny udział w powołaniu Związku Patriotów Polskich oraz 1 DP im. Tadeusza Kościuszki. Pisała teksty poświęcone problematyce wojennej: Płomień na bagnach (1940), Tęcza (1943), Po prostu miłość (1945). Po wojnie nie wróciła do kraju. Razem z czwartym mężem Aleksandrem Korniejczukiem zamieszkała w Kijowie. Zmarła 29 lipca 1964 roku, mając zaledwie 59 lat.

Pomimo oddalenia Wasilewskiej od kraju w okresie PRL-u chętnie wznawiano jej powieści. W 1954 roku opublikowano jednotomowy zbiór opowiadań W. Wasilewskiej, adresowany do młodego pokolenia pt. Utwory dla młodzieży31, w skład którego weszły wszystkie jej utwory dla dzieci i młodzieży, także te drukowane w czasopismach. Autorką wstępu do tego wydania była przyjaciółka pisarki - Janina

30W. Wasilewska, Pokój na poddaszu, Warszawa 1977, s. 98.

31W. Wasilewska, Utwory dla młodzieży, przedm. J. Broniewska, Warszawa 1954. 


\section{Broniewska ${ }^{32}$. Znajoma Wasilewskiej na temat jej utworów dla dzieci i młodzieży odnotowała:}

Każdy z zawartych w tym tomie utworów, drobne opowiadanie czy cała powieść, to dokument walki Wandy Wasilewskiej o dziecko robotnicze i chłopskie zatruwane propagandą wrogów robotnika i chłopa. To przeciwwaga reakcyjnego wychowania, które miało jeden tylko cel - wychować dzieci przeciw własnej klasie robotniczej, na posłusznych, a więc tanich najemników, przysparzających bogactw fabrykantom i obszarnikom. Utwory literackie Wandy Wasilewskiej dla dzieci i młodzieży to świadectwo miłości ojczyzny, prawdziwej ojczyzny ludu pracującego 33

Utwory Wasilewskiej adresowane do dzieci i młodzieży cechuje plastyczność oraz malarskość opisu, które pisarka osiągnęła stosując liczne porównania i metafory. Opowiadania bogate są w środki stylistyczne, szczególnie w epitety i związki frazeologiczne. Wyrazem folklorystycznych i etnograficznych zainteresowań autorki są wplatane w utwory różnego rodzaju pieśni i przyśpiewki np.:

\section{1) góralskie:}

Panowie, panowie, będziecie panami,

Ale nie będziecie przewodzić nad nami.

Polana, polana nie jednego pana,

Polanę skosili, pana obwiesili.... ${ }^{34}$

32 Janina Broniewska z domu Künig (ur. 5 sierpnia 1904 r. w Kaliszu, zm. 17 lutego 1981 r. w Warszawie) - polska pisarka, autorka powieści dla dzieci i młodzieży, publicystka, pedagog. W 1933 r. pozbawiono ją prawa do nauczania. W latach 1934-37 redagowała pisma dla dzieci „Płomyk” i „Płomyczek” i pisała książki dla dzieci. W czasie II wojny światowej przebywała na terenach okupowanych przez ZSRR. Była działaczką Związku Patriotów Polskich i korespondentem wojennym Dywizji Piechoty im. Tadeusza Kościuszki oraz członkiem redakcji „Nowych Widnokręgów"; w 1944 r. posłanką do KRN. W 1947 r. powróciła do Polski. Została redaktorem naczelnym tygodnika „Kobieta” oraz redaktorem literackim „Kraju Rad”. Przyjaźń z Wasilewską oraz doświadczenia wojenne opisała w swoich utworach: Maje i listopady (1967), Tamten brzeg mych lat (1973) oraz w zapiskach $Z$ notatnika korespondenta wojennego (1953); Zob. Słownik biograficzny historii Polski, J. Chodera, F. Kiryk (red.), T. 1, Wrocław 2005, s. 154; Literatura Polska: przewodnik encyklopedyczny, J. Krzyżanowski, od 1976 C. Hernas (red.), T. 1, Warszawa 1984, s. 106.

33 J. Broniewska, Wstęp, [w:] W. Wasilewska, Utwory dla młodzieży..., s. 10.

34 W. Wasilewska, Królewski syn..., s. 449. 
Marzena Forma - Wanda Wasilewska jako autorka...

2) weselne:

O Krakowa jadę,

Krzemienista droga;

Dajże, dziewczę, buzi, Bój się Pana Boga!35

\section{Podsumowanie}

Utwory literackie przeznaczone dla młodzieży nie różnią się zbytnio ani omawianą problematyką, ani językiem od powieści wojennych i powojennych Wasilewskiej. Choć autorka wprowadza do nich elementy optymistyczne, cały czas poruszają te same tematy: wyzysk, nędzę i ubóstwo chłopów na wsi oraz dwuklasowość społeczeństwa polskiego. Odnaleźć w nich bez trudu można akcenty społeczne, moralne i patriotyczne. Pisarka często sięgała także po tematy ze świata przyrody, wykorzystywała zebrane w młodości piosenki, legendy oraz wątki z opowieści ludowych, które nadają melodyjności utworom. Warto zwrócić uwagę, że opowiadania (tak samo jak inne utwory Wasilewskiej) oparte zostały na autentycznym materiale i osobistych obserwacjach proletariatu krakowskiego. Wasilewska sytuuje swoje postacie na tle konkretnego środowiska, które doskonale znała. $\mathrm{Na}$ bohaterów swoich opowiadań, utrzymanych w konwencji realistycznej, wybiera dzieci z kręgu biedoty miejskiej oraz rodzin robotniczych, upośledzonych społecznie. Dzieci te jednak same mogą decydować o swoim losie, a nawet o przyszłości innych pokrzywdzonych sierot, ponieważ mają silnie rozbudowany instynkt opiekuńczy - starsze rodzeństwo wychowuje i utrzymuje młodsze. Pomimo wysokiego poziomu artystycznego utwory Wasilewskiej nie przetrwały próby czasu. Po przemianach ustrojowych Wanda Lwowna przestała już być patronką ulic, instytucji państwowych i szkół, a jej utwory wycofano z listy lektur szkolnych.

35Tejże, Wierzby i bruk, [w:] Utwory dla młodzieży..., s. 491. 


\section{Bibliografia:}

Białek J., Literatura dla dzieci i młodzieży w latach 1918-1939: zarys monograficzny, Wydawnictwa Szkolne i Pedagogiczne, Warszawa 1987.

Forma M., Działalność kulturalno-literacka Wandy Wasilewskiej w latach 1934-1945, „Zeszyty Naukowe Państwowej Wyższej Szkoły Zawodowej we Włocławku. Zbliżenia Cywilizacyjne. Edukacja, kultura, polityka" 2014, T. 10.

Forma M., Działalność polityczno-literacka Wandy Wasilewskiej w latach 1939-1943, [w:] R. Majzner (red.), Między prawdq a zwątpieniem. W poszukiwaniu obrazu przeszłości, T. 3, Wydawnictwo im. Stanisława Podobińskiego Akademii im. Jana Długosza, Częstochowa 2015.

Friszke A., Jeden z „niepokornych” Leon Wasilewski, [w:] L. Wasilewski, Pitsudski jakim go znałem, Muzeum Historii Polski, Warszawa 2013, s. 9-108.

Jan z Kolna - Polak, który odkrył Amerykę, http://www.dziennik.com/publicy styka/artykul/jan-z-kolna-polak-ktory-odkryl-ameryke (dostęp: 6.02.2017).

Lepszy K., Słownik biograficzny historii powszechnej do XVII stulecia, Wiedza Powszechna, Warszawa 1968.

Literatura Polska: przewodnik encyklopedyczny, J. Krzyżanowski, od 1976 C. Hernas (red.), T. 1, Państwowe Wydawnictwo Naukowe, Warszawa 1984.

Małgowska H., Nowa formuła powieści społecznej, [w:] A. Brodzka, Z. Żabicki (red.), Z problemów literatury polskiej XX wieku, T. 2, Państwowy Instytut Wydawniczy, Warszawa 1965.

Pobóg-Malinowski W., Leon Wasilewski. Szkic biograficzny, „Niepodległość” 1937, T. 16.

Słownik biograficzny historii Polski, J. Chodera, F. Kiryk (red.), T. 1, Zakład Narodowy im. Ossolińskich, Wrocław 2005.

Sokorski W., Adieu, burdel czyli notatnik intymny, Andy Grafik, ChicagoWarszawa 1992.

Stoczewska B., O Leonie Wasilewskim, http://www.omp.org.pl/stareomp/ index7c3b.html (dostęp: 15.01.2015).

Tazbir J., Kilka wierszy o Krzysztofie Kolumbie, „Przegląd Humanistyczny” 1993, nr 6.

Tazbir J., Polska sława Krzysztofa Kolumba, Warszawa 1991. 
Marzena Forma - Wanda Wasilewska jako autorka...

Tazbir J., Zainteresowanie Kolumbem w Polsce XIX i XX wieku, „Kwartalnik Historii Nauki i Techniki”, nr 34/3, http://bazhum.muzhp.pl/media// files/Kwartalnik_Historii_Nauki_i_Techniki/Kwartalnik_Historii_Nauki_i_ Techniki-r1989-t34-n3/Kwartalnik_Historii_Nauki_i_Techniki-r1989-t34n3-s463-482/Kwartalnik_Historii_Nauki_i_Techniki-r1989-t34-n3-s463482.pdf (dostęp: 06.02.2017).

Wasilewski Z., Słowo wstępne, [w:] A. Naborowska (oprac.), Wanda Wasilewska: wieczór literacki, Czytelnik, Warszawa 1954.

Wat A., Mój wiek. Pamiętnik mówiony, T. 1, Czytelnik, Warszawa 1990.

Zatorska H., Wanda Wasilewska, Wydawnictwa Szkolne i Pedagogiczne, Warszawa 1976.

\section{Źródła archiwalne:}

AAN, Wspomnienia Wandy Wasilewskiej nagrane w Zakładzie Historii Partii przy KC PZPR w styczniu 1964 r., tecz. osob. Wandy Wasilewskiej, sygn. 9599.

AAN, Akta Leona Wasilewskiego 1890-1936 [1937], tecz. osob. Leona Wasilewskiego, sygn. 390.

AAN, Z.A. Woźnicka, Wspomnienia o Wandzie Wasilewskiej, tecz. osob. Wandy Wasilewskiej, sygn. 9599.

AUJ, Teczka akt doktorskich Wandy Wasilewskiej-Szymańskiej, sygn. WF II 504.

\section{Opowiadania Wandy Wasilewskiej}

Wasilewska W., Wierzby i bruk, [w:] tejże, Utwory dla młodzieży, Czytelnik, Warszawa 1954.

Wasilewska W., Królewski syn, [w:] tejże, Utwory dla młodzieży, Czytelnik, Warszawa 1954.

Wasilewska W., Pokój na poddaszu, Ministerstwo Obrony Narodowej, Warszawa 1977.

Wasilewska W., Szlakiem przygód, [bw], Warszawa 1936.

Wasilewska W., Utwory dla młodzieży, przedm. J. Broniewska, Czytelnik, Warszawa 1954.

Wasilewska W., W pierwotnej puszczy, [w:] tejże, Utwory dla młodzieży, Czytelnik, Warszawa 1954. 